\title{
Human Myeloid Progenitor Cells CLT-008
}

National Cancer Institute

\section{Source}

National Cancer Institute. Human Myeloid Progenitor Cells CLT-008. NCI Thesaurus.

Code C82381.

Early-to late-stage myeloid progenitor cells derived from adult human stem cells with potential hematopoietic activity. Upon infusion, human myeloid progenitor cells CLT-008 proliferate into mature myeloid cells, including granulocytes, macrophages, platelets, and erythrocytes. These myeloid progenitor cells die within forty-five days after a burst of hematopoiesis. This agent cannot create lymphoid cells, including $T$ cells associated with graft-versus-host disease (GVHD). 